MACIEJ GÓRNY

Instytut Historii PAN, Warszawa

\title{
UŻYTECZNOŚĆ I GRANICE. EUROPA ŚRODKOWO-WSCHODNIA JAKO NARZĘDZIE BADAWCZE
}

Terminy Europa Środkowo-Wschodnia, Europa Środkowa, Europa Wschodnia i pokrewne są nie tylko narzędziami historycznej czy socjologicznej analizy. W ich przypadku, być może nawet w większym stopniu niż innych regionów, trudno abstrahować od politycznej historii pojęć. Nie są one „przezroczyste”. ów polityczny wymiar problemu jest zagadnieniem zbyt obszernym, by je tu szczegółowo omówić, ale zarazem na tyle ważnym, że nie wolno go pominąc ${ }^{1}$. W koncepcji Františka Palackiego z 1848 r. habsburska Europa Środkowa miała być zabezpieczeniem małych narodów przed imperializmem rosyjskim i niemieckim. W chwili, gdy czeski historyk formułował swoje tezy, polscy emigranci już od kilkudziesięciu lat dyskutowali o jakiejś formie politycznego związku na tym obszarze ${ }^{2}$. Równolegle od połowy XIX w. rozwijała się niemiecka refleksja nad regionem, której ostatecznie najbardziej wpływową formułę nadał w 1915 r. Friedrich Naumann. W tym przypadku podstawą związku politycznego miały być powiązania gospodarcze. W opozycji do teorii

\footnotetext{
${ }^{1}$ Wśród wielu opracowań poświęconych historycznemu kontekstowi pojęć Europa Środkowa, Europa Środkowo-Wschodnia i in. chciałbym przywołać dwa artykuły wyróżniające się szczególnie szeroką perspektywą czasową i terytorialną. W pewnym sensie teksty te są komplementarne, jeden bowiem uwzględnia rosyjski punkt widzenia, natomiast drugi uwypukla powiązania regionu z Niemcami: R. Okey, Central Europe / Eastern Europe: Behind the Definitions, „Past \& Present” 1992,137, s. 102-133; A. Miller, Die Erfindung der Konzepte Mittel- und Osteuropa, w: Europa und die Grenzen im Kopf, red. K. Kaser, D. Gramshammer-Hohl, R. Pichler, Klagenfurt 2004, s. 139-163.

${ }^{2}$ Por. np. polskie, niemieckie i węgierskie koncepcje regionalne XIX i XX w. zebrane w publikacji Option Europa. Deutsche, polnische und ungarische Europapläne des 19. und 20. Jahrhunderts, red. W. Borodziej i in., t. 1-3, Göttingen 2005.
} 
i praktyki niemieckiej polityki wobec Europy Środkowo-Wschodniej Tomáš Garrigue Masaryk i inni autorzy wydawanej przez Roberta W. Setona-Watsona „The New Europe” ożywili część idei Palackiego, opisując region jako przestrzeń zamieszkaną przez małe narody, zagrożone tym razem bardziej przez Niemcy niż przez Rosję. W okresie międzywojennym obie te intelektualne tradycje znajdowały kontynuatorów, wśród których szczególną rolę odegrał Oskar Halecki. W sporze z Jaroslavem Bidlo przeciwstawiał „cywilizacyjny” podział kontynentu preferowanemu przez czeskiego historyka wyznaniowemu. Równolegle w Niemczech nastąpił dynamiczny rozwój studiów nad geopolityką, w których liberalna koncepcja Naumanna niemieckiej dominacji w regionie nabierała coraz bardziej złowróżbnych kształtów. W niemieckiej Ostforschung, interdyscyplinarnej szkole badań nad niemieckim Kulturraum, Mitteleuropa była terenem dominujących wpływów niemieckiej kultury. Dla niemieckich historyków i geografów interesujące były „wyspy” tej ostatniej, nie zaś otaczające je „morze” ludności miejscowej.

Wiele tych politycznych, ekonomicznych i literackich koncepcji regionu jest wartych lektury nie tylko ze względu na treść, ale i na formę. Refleksja nad charakterem Europy Środkowo-Wschodniej to ważny (choć nie centralny) rozdział historii myśli politycznej prawie wszystkich krajów, które zaliczają się do regionu w jakiejkolwiek wersji. Właśnie ta polityczność sprawia, że również naukowa dyskusja krążyła wokół kwestii granic. Ciągłym elementem polskiego myślenia o Europie Środkowo-Wschodniej są jej wschodnie rubieże - Borderlands of Western Civilisation - jak brzmi tytuł programowej książki Haleckiego (1952). Kwestia, kto nie należy do regionu, jest w takiej optyce co najmniej równie ważna, jak pytanie, kto się do niego zalicza. W publikacjach zainspirowanych Naumannem i niemiecką geopolityką trudno nie dostrzec z kolei ,inkluzywnego” dążenia do wyznaczania możliwie szerokich granic niemieckich wpływów kulturowych, które odpowiednio pielęgnowane mogłyby stać się wpływami politycznymi, a wreszcie dać okazję do uznania tak wyznaczonego regionu za część Niemiec. Drastyczny przykład takiej ewolucji stanowi polityka narodowościowa i osadnicza III Rzeszy w Protektoracie Czech i Moraw, okupowanej Polsce, na Ukrainie, Białorusi i w państwach bałtyckich. Początkowo jej celem było pozyskiwanie etnicznych Niemców, osiedlanych na terenie starej Rzeszy i na terytoriach do niej przyłączonych. Sytuacja w Kraju Warty i Alzacji-Lotaryngii różniła się przy tym raczej pod względem stopnia okrucieństwa i bezwzględności niż zakładanych celów polityki narodowościowej. Perspektywa wielkich zdobyczy terytorialnych na Wschodzie w 1941 r. diametralnie zmieniła sytuacje i kierunek, $w$ którym podążali niemieccy osadnicy.Zamojszczyzna i okolice Żytomierza były tylko pierwszymi ele- 
mentami planu uczynienia z Europy Środkowo-Wschodniej niemieckiej kolonii. Metody, za pomocą których dążono do tego celu, były bezprzykładne, ale idee nie odbiegały zbyt daleko od geopolitycznych koncepcji Karla Haushofera ${ }^{3}$.

To wyjątkowo drastyczny przykład, ale myślenie o granicach Europy Środkowej czy Środkowo-Wschodniej generalnie rzadko pozbawione było politycznych intencji. Aleksej Miller zwraca uwagę na uwarunkowania ostatniego „wybuchu” zainteresowania tematem na Zachodzie w latach osiemdziesiątych XX w. Upadek marksistowskiej lewicy, Solidarność w Polsce, interwencja ZSRR w Afganistanie, a nawet antyamerykańskie nastroje zachodnioeuropejskiej opinii publicznej - wszystko to zwiększało rezonans wywołany przez esej Zachód porwany albo tragedia Europy Środkowej Milana Kundery (1983). Przytaczając ironiczny komentarz Josifa Brodskiego, Miller sprowadza tezy Kundery do prostego przesłania: kraje regionu są częścią Zachodu, a z Rosją nie mają nic wspólnego ${ }^{4}$. Jak dodaje Stefan Troebst, niemal każdy historyczny region funkcjonuje na trzech, warunkujących się wzajemnie, poziomach: polityki, map mentalnych i historiografii. Historycy nie tylko nie uciekają od ich politycznych konotacji, ale czasem wręcz na nich najbardziej im zależy ${ }^{5}$.

I nie koniec na tym. O ile bowiem Europa Środkowo-Wschodnia czy Europa Środkowa są stosunkowo szeroko akceptowane zarówno na zewnątrz, jak i wewnątrz tak czy inaczej wyznaczanych regionów, o tyle Europa Wschodnia to raczej stygmat. Kwestią sporną pozostaje, czy opisywane przez Larry'ego Wolffa rozumienie tego regionu jako nieudanej kopii Zachodu istotnie pojawiło się już w oświeceniu ${ }^{6}$. W każdym razie ma ono orientalizujący posmak, podobny do przeważnie negatywnie kojarzonych Bałkanów ${ }^{7}$.

${ }^{3}$ Na ten związek zwraca uwagę Isabel Heinemann, „Rasse, Siedlung, deutsches Blut”. Das Rasse- und Siedlungshauptamt der SS und die rassenpolitische Neuordnung Europas, Göttingen 2003.

${ }^{4}$ A. Miller, op. cit., s. 147-149.

${ }^{5}$ S. Troebst, What's in a Historical Region? A Teutonic Perspective, „European Review of History" 10, 2003, 2, s. 173-188, tu s. 187.

${ }^{6}$ L. Wolff, Inventing Eastern Europe: The Map of Civilization on the Mind of the Enlightenment, Stanford, Calif. 1995; krytyka podejścia Wolffa w: B. Struck, Nicht West - nicht Ost. Frankreich und Polen in der Wahrnehmung deutscher Reisender zwischen 1750 und 1850, Göttingen 2006.

7 O orientalizacji Bałkanów zob. M. Todorova, Imagining the Balkans, New York-Oxford 1997; V. Goldsworthy, Inventing Ruritania. The Imperialism of the Imagination, New Haven-London 1998. 
Hipoteka ciążąca na interesujących mnie terminach jest więc poważna. I to właśnie ona w większym stopniu niż kolejne metodologiczne przełomy sprawia, że trzeba się z użycia tych słów tłumaczyć. Po 1989 r. odbyło się co najmniej kilka ciekawych dyskusji o perspektywie „unaukowienia" refleksji nad regionem. Przeważały głosy optymistyczne. W jednym z najciekawszych wystąpień, w tematycznym numerze „European Review of History” z 1999 r. Maciej Janowski podjął próbę wydobycia $z$ tego wielowarstwowego dyskursu konkretnych dyrektyw badawczych. Opowiadając się za Europą Środkowo-Wschodnią (obejmującą Austro-Węgry sprzed 1918 r. oraz wszystkie terytoria należące kiedykolwiek do Rzeczypospolitej), wyraził nadzieję, że historia ujęta w ramy większego regionu pozwoli pokonać niektóre ograniczenia historii narodowych. Skupił się na trzech korzyściach wynikających z uprawiania historii Europy Środkowo-Wschodniej. Po pierwsze: oddanie głosu tym wszystkim narodowościom i grupom społecznym, na które w narodowych narracjach brak miejsca lub pozostają w nich na marginesie. Po drugie: wyostrzenie uwagi na dwoisty charakter wpływów kulturowych w regionie, odbijający się w takich fenomenach jak choćby sarmatyzm. Po trzecie wreszcie: porównanie pozornie niekompatybilnych chronologii i terminologii narodowych historii, pozwalające na odróżnienie tego, co rzeczywiście jest narodową specyfiką, od tego, co tylko zwykliśmy inaczej nazywać ${ }^{8}$.

Janowski wymienił szereg przykładów, w których podejście regionalne okazało się szczególnie wartościowe. Nie chcąc powtarzać nazwisk i tytułów dzieł, skupię się na tematach, które - jak sądzę - układają się w pewien wzór kwestii szczególnie „podatnych” na ujęcia regionalne. Należy do nich bez wątpienia historia kultury i ustroju nowożytnych państw stanowych. Pokrewnym, posiadającym szczególnie długą i cenną tradycję badawczą zagadnieniem jest gospodarka Europy Środkowo-Wschodniej. W najróżniejszych formach (od „ustroju folwarczno-pańszczyźnianego”, poprzez „drugie poddaństwo" i „pruską drogę do kapitalizmu” z marksistowskich dyskusji na przełomie lat pięćdziesiątych i sześćdziesiątych aż po koncepcję „żywnościowej peryferii zachodniego centrum” Ivána Berenda i Györgya Ránkiego) pojawia się w tym nurcie pytanie o charakter i źródła wschodnioeuropejskiego zacofania ${ }^{9}$. Kolejnym zagadnieniem z powodzeniem analizowanym w ujęciu ponadnarodowym jest proces narodotwórczy. Nawet jeśli pewien schematyzm modelu wypracowanego przez Miro-

${ }^{8}$ M. Janowski, Pitfalls and Opportunities. The Concept of East-Central Europe as a Tool of Historical Analysis, „European Review of History” 6, 1999, 1, s. 91-100, tu s. 96-97.

${ }^{9}$ Znakomitą analizę polskiej i międzynarodowej dyskusji przedstawiła Anna Sosnowska, Zrozumieć zacofanie. Spory historyków o Europę Wschodnią (1947-1994), Warszawa 2004. 
slava Hrocha (a także Józefa Chlebowczyka) wywołuje krytykę, pozostaje inspirujący między innymi dzięki dobremu osadzeniu w historii Europy Środkowo-Wschodniej ${ }^{10}$. Czwarty „,wielki” temat, który rozwija się właściwie na naszych oczach, to szeroko rozumiana historia idei w Europie Środkowo-Wschodniej ${ }^{11}$. W tych ramach mieści się historia lokalnych adaptacji zachodnioeuropejskich prądów kulturowych i politycznych, specyficzna rola inteligencji jako wyróżnika regionu, porównawcza historia historiografii czy literatury.

Cztery (co najmniej, bo można by przecież zastanawiać się choćby nad nośnością koncepcji wczesnośredniowiecznej „młodszej Europy” albo nad środkowo- i wschodnioeuropejską historią społeczną) zagadnienia obrosłe dziesiątkami publikacji to wystarczająco wiele, by postawić pytanie nie tyle o sens ujęć regionalnych, ile raczej o nadawane im znaczenia. Przywołane wyżej kierunki badawcze nie odnoszą się w równym stopniu do wszystkich koncepcji Europy Środkowo-Wschodniej. Dyskusja o regionalnym zacofaniu operuje raczej pojęciem Europy Wschodniej niż Środkowo-Wschodniej. To drugie dobrze się sprawdza - jak sądzę - w historii idei czy kultury. Chodzi nie tylko o to, że przynależność, powiedzmy, białoruskich kresów II Rzeczypospolitej do tej samej regionalnej struktury co Czechy jest bardziej oczywista w historii intelektualnej niż gospodarczej. Pewne tematy wymagają rozszerzenia perspektywy. Mówiąc obrazowo: Paryż czy Berlin XIX w. w pewnym sensie przynależą do historii Europy Środkowo-Wschodniej, wcześniej - raczej nie. Płynność granic dotyczy jednak nie tylko przestrzeni, ale również czasu. Epoki literackie „rozmijają się" nieraz o kilka dziesięcioleci, tak że na obrzeżach regionu trudno o uchwycenie różnicy między romantyzmem i neoromantyzmem ${ }^{12}$.

Ta płynność pojęć w praktyce badawczej oznacza nic innego jak otwarcie na histoire croisée. Philipp Ther przekonywająco dowodzi (krytykując przy tym autorów najgłośniejszych syntez historii Niemiec ostatniego ćwierćwiecza), że konieczne jest uwzględnienie relacyjności różnych narodowych i nienarodowych - historii ${ }^{13}$. Innymi słowy, należy (dodajmy,

${ }^{10}$ Por. numer specjalny „Nationalities Papers” 38, 2010, 6 pt. Twenty-Five Years of A-B-C. Miroslav Hroch's Impact on Nationalism Studies.

${ }^{11}$ Aktualnie trwaja prace nad syntetycznym opracowaniem zbiorowym Negotiating Modernity: History of Modern Political Thought in East-Central Europe, 〈http:// negotiating.cas.bg/> (dostęp: 16 V 2012).

${ }^{12}$ Cały szereg chronologicznych niespójności przy zachowaniu podobnej struktury historii idei dokumentuje edycja źródłowa Discourses of Collective Identity in Central and Southeast Europe, t. 1-3, red. A. Ersoy i in., Budapest-New York 2006-2010, t. 4 w druku.

${ }^{13}$ P. Ther, Beyond the Nation: The Relational Basis of a Comparative History of Germany and Europe, „Central European History” 36, 2003, 1, s. 45-73. 
w miarę zdrowego rozsądku i własnych możliwości) przekraczać granice swojego tematu. Przykładem, na który często powołują się niemieccy autorzy, jest pionierska analiza historii Polski i Rosji pióra Klausa Zerna$\mathrm{cka}^{14}$. Jej autor w podobnych kategoriach traktuje również inne europejskie sąsiedztwa. Zernack zadaje np. retoryczne pytanie: „Czy uporczywość, z jaką historia wzajemnych oddziaływań między dwoma europejskimi narodami Polaków i Niemców wpływa na ich aktualne wzajemne stosunki, nie stanowi wystarczającego powodu, by dokonać historycznej problematyzacji historii stosunków między nimi jako czynnika oddziaływania sui generis?"15.

Płynność terytorium regionu, elastyczna chronologia, relacyjność całego regionu i poszczególnych jego części (a także poszczególnych zachodzących w nich zjawisk) - wszystkie te postulaty mogą budzić wątpliwość, czy ich realizacja nie pociągnie za sobą ostatecznego rozmycia granic Europy Środkowo-Wschodniej. Nie jest to możliwość czysto teoretyczna. W ostatnim czasie ukazało się kilka książek podejmujących próbę realizacji tych założeń. Odniosę się do dwóch, których autorzy - co znamienne - są absolwentami uczelni niosącej Europę Środkową w nazwie ${ }^{16}$. Obie prace dotyczą historii idei. Monika Baár porównała pięciu romantycznych historyków z Europy Środkowo-Wschodniej, dochodząc do wniosku, że utrwalona w historiografii interpretacja ich dzieł w kontekście procesów narodotwórczych specyficznych dla regionu jest nieuzasadniona. Ich sposób myślenia o historii i spojrzenie na narodową przeszłość mieściły się w tych samych ramach co w przypadku historyków z Europy Zachodniej: ,przy dokładniejszym badaniu narracja historyczna ujawnia ogólny wzór narodowej historiografii naszej epoki, składający się z centralnej opowieści i rozlicznych, wszechobecnych jej odbić"17. Z kolei brak oryginalności niektórych koncepcji Joachima Lelewela, Simonasa Daukantasa czy F. Palackiego skłania do analizowania ich w kontekście innych europejskich peryferii. Otwarcie na relacyjność w przypadku tego tematu zaowocowało krytyką esencjalistycznego podtekstu dziejów nacjonalizmu w naszym regionie. Drugim przykładem, który chciałbym przywołać, jest krótka historia europejskiego

${ }^{14}$ K. Zernack, Polska i Rosja. Dwie drogi w dziejach Europy, Warszawa 2000 (oryg. niem. 1994).

${ }^{15}$ Idem, Tysiąc lat dziejów stosunków niemiecko-polskich jako obszar problemowy badań historycznych oraz postulat badawczy, w: Niemcy - Polska. Z dziejów trudnego dialogu historiograficznego, red. H. Olszewski, Poznań 2006, s. 67.

${ }^{16}$ Uniwersytet Środkowoeuropejski w Budapeszcie (Central European University).

17 „on closer inspection the historical narrative reveals the existence of a general template of national historiography in our era, which comprised a core story and numerous omnipresent tropes", M. Baár, Historians and Nationalism. East-Central Europe in the Nineteenth Century, Oxford 2010, s. 295 
ruchu eugenicznego pióra Mariusa Turdy ${ }^{18}$. Inaczej niż u Baár, Europa Środkowo-Wschodnia nie staje się w ogóle tematem opracowania. Autor nie snuje też żadnych refleksji o miejscu regionu w kontekście analizowanego przezeń zagadnienia. Historia, którą opisuje, prawdziwie europejska, swobodnie przemieszcza się pomiędzy krajami, podążając za ideami biologicznymi i prawnymi. Obecność „Wschodu” ma w niej wymiar całkowicie praktyczny. Turda pokazuje, że transfer idei nie był jednokierunkowy, że np. w niektórych aspektach eugenika w państwach bałtyckich była „nowocześniejsza” niż we Francji, a uczestnicy owego polityczno-biologicznego dyskursu zdawali sobie z tego sprawę.

Czy oba te przykłady świadczą o tym, że wraz z pojawieniem się nowych trendów metodologicznych Europa Środkowo-Wschodnia przestaje być potrzebna? Czy poszerzanie perspektywy sprawia, że region przestaje mieć jakiekolwiek znaczenie? Nie. Uważam, że zjawisko, które ilustrują książki Baár i Turdy, nie musi polegać na odrzuceniu regionalnego podziału, tylko na otwarciu dyskusji nad jego treścią. Już w przywoływanym powyżej artykule z 1999 r. M. Janowski zwrócił uwagę na konflikt koncepcji Europy Środkowo-Wschodniej jako obszaru cywilizacyjnego zacofania (a więc w perspektywie procesów modernizacji) i ujęć postmodernistycznych, które koncepcję modernizacji odrzucają w całości lub też kładą nacisk na zmienność tego terminu ${ }^{19}$. Analiza dyskursu - a jej właśnie dotyczy zarówno książka Baár, jak i Turdy - pozwala na nowo ustawić ramy porównań i granice badanego obszaru. Możliwości są szerokie i nie muszą się one ograniczać do Europy. Kilkadziesiąt lat temu analogiczne porównawcze ujęcia, osadzone w innych tradycjach badawczych, przedstawiali Marian Małowist czy Antoni Mączak. Tamto poszerzenie perspektywy nie unieważniło Europy Wschodniej jako użytecznego narzędzia badawczego. To obecne, dotyczące historii dyskursów, moim zdaniem także tego nie uczyni.

Europa Środkowa, Wschodnia, Środkowo-Wschodnia i inne pokrewne określenia mają bowiem kilka zalet, które historycy cenią szczególnie. Powstała bogata tradycja badawcza tych pojęć, tu już wspomniana, do której można się odwoływać choćby po to, by podawać ją w wątpliwość. Region łączą geografia, klimat, podobieństwa krajobrazów kulturowych i doświadczeń historycznych. Co więcej, jest on nader często po prostu kategorią źródeł wytwarzanych poza nim, do których historycy się odwołują. Trochę jak w przypadku regionalnych walut i gospodarek. Kiedy jedno z państw regionu przeżywa kryzys, pozostałe mnożą wysiłki, by przekonać tzw. rynki, że

${ }^{18}$ M. Turda, Modernism and Eugenics, Basingstoke 2010.

${ }^{19}$ M.Janowski, op. cit., s. 99. 
one z problemem tym nie mają nic wspólnego. Inwestorzy (i nie tylko oni) myślą w kategoriach regionalnych, co samo w sobie jest niedającym się ignorować faktem. Niemałe znaczenie ma także polityczny wymiar idei Europy Środkowej - „silnego”, a więc rozpoznawalnego i budzącego zainteresowanie regionu ${ }^{20}$.

Wszystkie te zalety sprawiają, że Europa Środkowo-Wschodnia dysponuje potencjałem, dzięki któremu nie „przegra” z historią globalną, historią Europy czy też peryferii Zachodu. W każdej z tych optyk może odgrywać ona poważną rolę. Istotne wydaje mi się, żeby tę i inne koncepcje regionalne traktować jako narzędzie badawcze, a nie cel sam w sobie. Włączanie w ich ramy poszczególnych krajów czy też ich usuwanie często ma sens, ale definiowanie instrumentarium badawczego nie powinno przeszkadzać w używaniu tych instrumentów w praktyce. Analogicznie do innych używanych przez historyków pojęć Europa Środkowo-Wschodnia musi pozostać lekko rozmyta, by zachować swą użyteczność. Jej granice mogą (i chyba powinny) być płynne. $Z$ tego zresztą słynie nie od dziś.

${ }^{20}$ S. Troebst, op. cit., s. 187. 